\title{
The Life and Death of the Great European Boom
}

\author{
Alan S. MILWARD
}

\begin{abstract}
Assumptions
The usual measurements of the Great European Boom which are used to identify it as a distinct phenomenon with a distinct periodization are two; high GNP growth rates and the stability of employment and other cyclical indicators. ${ }^{1}$ It has conventionally been periodized from 1950 onwards by these measures, but that has been merely to suit the data - gathering convenience of economists; internationally standardized data series published in convenient series by international agencies begin in 1950-51. This discussion paper assumes that the data accumulated by historical research has demonstrated that in fact the boom began in 1945 and can only be understood as a phenomenon if it is dated from then. Giving an end-date to the boom is however much more difficult because it depends on our interpretation of it and of subsequent events. Statistically, there are two possibilities, 1968 or 1974, and I leave these possibilities open for discussion in the paper.

Because the paper aims to build a dynamic political economy into existing models and interpretations of the boom, it deals only with the European boom. This is inevitably arbitrary and misleading but it is done to avoid even more excessive generalization than I have already permitted myself here. The movement of growth and of productivity in the USA is distinctly different over the whole period from 1945 to now. The pattern of employment differs from the European pattern throughout the whole period, and especially so in the 1980s. It is probably true that the international monetary hegemon has to play by rules so different that they must exercise a strongly differentiating impact on domestic economic phenomena.

Lastly, I am assuming a certain familiarity with much of the work cited here. I have done this to liberate myself from footnotes whose purpose would be merely bibliographical in order to lighten the paper so that it may lead to a more wide-ranging interdisciplinary discussion, not so much about what has been done as about what might be done next. ${ }^{2}$
\end{abstract}

1. Editorial note: This paper was written at the beginning of 1996. The rest of the footnotes in this text are editorial notes; none was in the original text.

2. References have been added to help those readers who might be unfamiliar with the literature. 


\section{General Descriptions of the Great Boom}

Factor analysis of the high growth rates in Western Europe, while leaving by most estimates about 60 per cent of the total growth unaccounted for, pointed the way in the 1960s to two particular lines of interpretation, one stressing the observed statistical importance of higher levels of capital investment and the other the great relative increase in labour inputs.

Investment inputs were undisputedly higher after 1945 than in earlier or later historical periods and for this some historical explanation is required. The effects of this phenomenon are, however, much disputed. Few economists now accept that there is any proven connection between higher investment and higher output. Historians, measuring these connections over longer periods, have been less abstractly agnostic but deeply sceptical of the view that higher investment in any period will yield higher output in the same period. This is perhaps because so many historians' measurements relate to the nineteenth century when so high a proportion of measured investment was infrastructural, with a longer-run yield. However, even in the 1960s when the higher investment levels were the favourite academic explanation for the boom, the detailed measurement of capital/output coefficients revealed such large differences as to call this explanation into serious question. Norway was consistently for thirtyfive years the country where the largest share of GNP went into new investment and consistently the country with lowest capital/output coefficients. Investment as a proportion of GNP relative to other Western European countries was not significantly different in France - a high growth rate country and one of the only two countries where GNP growth rates were significantly higher in the 1960s than the 1950s - than in Denmark a low growth rate country.

If these comparisons are pushed back to 1945 , as they have to be, the impact of investment on output growth becomes a much more complicated issue still because of the problem of capacity utilization. This is a statistical black hole which has never been filled. Any given unit of investment in the West German economy after 1945 was likely to produce a far higher increase in output than in, for example, the British, Belgian, Norwegian or Swedish economies. With, uniquely in Western Europe, high levels of industrial investment since 1934, with the capital stock in summer 1945 still at the level it had reached by June 1944, and with the stock of productive machinery at a yet higher level, the West German economy had a far higher value and a far wider range of unutilized and underutilized capacity than any other. This is merely one indication of the lack of historical specificity of capital investment ratios as predictors of GNP growth rates. Merely looking at the distribution of investment in Western Germany might suggest low productivity growth rates since, together with the United Kingdom, it had the highest share of total investment going into residential construction throughout the 1950s. In fact it had the highest productivity growth rates.

The impact of investment on the growth rate of overall productivity is normally thought to come through embodied technology. Since however there were large increases in employment in manufacturing between 1945 and 1960 in western Europe, 
continuing into the 1960s in Germany, it has always been necessary to link investment to foreign trade in explanations of the great boom. Higher labour productivity permitted a growth in absolute numbers in employment because output expanded so rapidly and for so long. In the absence of generally falling prices, although the prices of many consumer goods where output growth was particularly fast did fall, the explanation depended on a deus ex machina - trade liberalization. Trade liberalization permitted scale economies, and the ensuing increase in overall productivity in manufacturing rose faster in a sufficient number of countries than labour costs. In the $1950 \mathrm{~s}$ it is the case that the rate of growth of foreign trade in almost all West European countries was faster than that of output, but this was less generalized, and diminishing, as a phenomenon in the 1960s. Recent more detailed analysis of trade liberalization however - including my own study of quantitative restrictions to be published in spring - all show that it was in the 1960s, not the 1950s, that it mainly took place, thus coinciding with a slowdown in rates of growth of GNP and productivity. ${ }^{3}$

Trade liberalization was never a convincing deus ex machina, because as all endogenous growth models would imply some incentive is needed to explain why countries would liberalize trade. In the exogenous models of the 1960s this question was by-passed by making the liberal assumption that free-trade axiomatically generated welfare and income gains, ignoring the crucial difference between gains to mankind and gains to national governments, the agencies that actually liberalize.

Such exogenous models were greatly influenced by Petrus J. Verdoorn's so-called law, purporting to correlate increases in the size of total markets with increases in manufacturing productivity and by inter-country comparisons which tended to show that countries with the highest rates of productivity increase also had the highest rates of foreign trade growth, and, additionally, encountered the least balance of payments difficulties. This last point of course was always emphasized in relation to the balance of payments problems of the British economy throughout the great boom, which were attributed to 'stop-go' policies by the government. Balance of payments difficulties would be met by higher interest rates of which lower GNP growth rates were held to be the consequence. Nicholas Kaldor and Alexandre Lamfalussy both built on Verdoorn's large assumptions to explain the rank-order of growth rates in Western Europe in terms of foreign trade success. ${ }^{4}$ For Lamfalussy the competition between rapidly growing national economies was not unlike that between riders on the wall of death. The fastest initial accelerator, Germany, followed by the Netherlands, would not only reach the top of the cylinder first but could not be overtaken on the way, because productivity growth rates would, by virtue of the foreign trade position of

3. The author refers to A.S. MILWARD, G. BRENAN, Britain's Place in the World: A Historical Enquiry into Import Controls, 1945-60, Routledge, London, 1996.

4. A. LAMFALUSSY, Investment and Growth in Mature Economies. The Case of Belgium, Macmillan, London, 1961; and The United Kingdom and the Six. An Essay on Economic Growth in Western Europe, Macmillan, London, 1963; N. KALDOR, Essays on Economic Stability and Growth, Gerald Duckworth \& Co., London, 1960; Causes of the Slow Rate of Economic Growth in the UK, Cambridge University Press, Cambridge, 1966; and Conflicts in National Economic Objectives, in: Economic Journal, March(1971), pp.1-16. 
those countries, not be overtaken by the growth rate of labour costs. Down at the bottom, the United Kingdom or Denmark (or the USA), the position was the reverse. Only a huge external shock, stopping the cylinder's motor, could change the pattern. All that was needed was to explain why some countries had a more rapid initial acceleration.

Here Lamfalussy, and in this he was joined by much quasi-Marxist analysis, found the answer in the other factor which emerged from growth analysis as having some explanatory power, labour. Germany and the Netherlands had the lowest labour costs in Western Europe when the cylinder started to spin. Their exports were cheaper and thus their productivity growth rates higher. They were closely followed by Italy. The rate of increase of German wages and social security costs borne by employers was in fact much higher between 1945 and 1960 than that in Britain (or the USA), but it is true that the initial starting point was much lower and the rate of increase of overall manufacturing productivity much steeper.

Labour inputs as well as labour costs over the period of the boom were not of course determined solely by the domestic supply of labour. For twenty-five years Western Europe replaced the USA as the main target of immigration. The large numbers of immigrants as well as the rapid shrinking of the agricultural labour force determined the supply of labour in a long period of full employment, and both sources of supply varied widely between countries. Charles Kindleberger went so far as to argue that the release of labour from the primary sector coupled with immigration was in fact the main cause for the length of the boom; the drying up of inter-sectoral labour transfers and the reversals of immigration policies after 1968 the main cause of its end..$^{5}$ If investment depended on the rate of return to capital, and if that depended on labour costs, variations between the supply of labour might explain variations in growth rates, and the completion of inter-sectoral transfers within the economy might explain the lower levels of employment after 1968-74.

Immigration in the 1960s accounted for roughly 50 per cent of the net increase in the labour force in the German economy, whereas in the United Kingdom, where the agricultural sector was already too small to provide much labour through inter-sectoral transfers, immigration was relatively low. Robert C. Matthews and John C. Odling-Smee are able to demonstrate convincingly that shortages of labour slowed down the rate of GNP growth in the United Kingdom at its peaks. ${ }^{6}$ But there are too many inconsistencies in comparison for this explanation to have general validity either.

The annual average absolute number of people leaving the agricultural sector for employment elsewhere throughout the boom was more or less the same in Germany and France, yet France with higher wage and social security costs on employers, and where immigrants were only 25 per cent of the net increase in the labour force between

5. C.P. KINDLEBERGER, Europe's Postwar Growth. The Role of Labor Supply, Harvard University Press, Cambridge (Mass.), 1967.

6. R.C. MATTHEWS, C.H. FEINSTEIN, J.C. ODLING-SMEE, British Economic Growth, Clarendon Press, Oxford, 1982. 
1959 and 1968 had a higher rate of GNP growth than Germany. Norway and Sweden with a rate of increase of labour supply comparable to that of the United Kingdom had a higher rate of growth of GNP than Belgium which had a large reserve of unemployed skilled industrial workers in the 1950s. Andrew Glyn and John Harrison's painfully constructed index of returns to capital throughout the boom does show a steadily diminishing rate of return to capital and this does correlate, roughly, with increasing costs of labour. ${ }^{7}$ But in any particular manufacturing sector where output does increase particularly rapidly most measurements show, as might be expected, that labour costs were a diminishing share of total manufacturing costs. Where this was not so competition from NICs in spite of complex international market management was nevertheless successful.

To a certain extent the arguments which have been derived from factoring out GNP growth in this way have been neatly subsumed into a more comprehensive framework by Moses Abramovitz and others who have explained the great European boom essentially as a catching-up process, the convergence in productivity growth rates which is to be expected in any relatively open world trading system. ${ }^{8}$ Catch-up depended on the transfer of technology from the highest overall productivity country, the USA. Estimates, which vary rather widely, do suggest that as far as productivity in manufacturing is concerned the gap did close, so that for example by the early 1970s productivity in Germany was somewhat over 90 per cent that of the USA, with others strung out.

But in better estimates, those of Stephen Broadberry for example, the gap between leader and most followers remains so wide as to cast much doubt over the idea of catch-up as a comprehensive explanation. ${ }^{9}$ Neither do such estimates convincingly demonstrate that productivity growth rates do, as a norm, converge. Most comparative studies of productivity growth show that its rate depends on such complex and numerous sets of social and economic variables that the failure to identify, except in one or two technologies such as car manufacture, the precise transfers of technology that contributed to catch-up is no good reason for rejecting the concept. What is more troubling to the historian is the unproven theoretical assumption that there is a "normal' trend of growth such that economies falling behind trend, as most western European economies did in the inter-war period, will, given favourable international circumstances, make up the lost growth. While the proposition might be theoretically useful, it is too teleological to make good history.

Much the same can be said about the other generalized comprehensive explications of the great boom. Its birth and its death are in all these models conjuncturally determined. Neither policy nor the ideas that inform it make any significant differ-

7. P. ARMSTRONG, A. GLYN, J. HARRISON, Capitalism since World War II. The Making and Breakup of the Great Boom, Fontana, London, 1984.

8. M. ABRAMOVITZ, Catching-up, Forging Ahead, and Falling Behind, in: The Journal of Economic History, June(1986), pp.385-406, and The Catch-Up Factor in Postwar Economic Growth, in: Economic Inquiry, January(1990), pp.1-18.

9. S. BROADBERRY, Manufacturing and the convergence hypothesis: what the long-run data show, in: The Journal of Economic History, 4(1993), pp.772-795. 
ence, except perhaps in so far as they were permissive; governments did not intervene to prevent growth, nor did they have any power later to correct the movement to lower growth rates and high unemployment.

\section{Policy and Economics in the Great Boom}

The only category of explanation that falls outside these general categorizations is, ironically, that of the pioneering producer of the data on which the other explanations are based. Angus Maddison was, and remains, a firm believer in the role of government policy in generating and maintaining the great boom. Government sustained high and steady levels of demand and exercised so much greater

'a role in the economy that its operations largely determine the general economic momentum, and what appears as the business cycle is nowadays mainly a reflection of phases in government policy'. ${ }^{10}$

Rather similar ideas were expressed by writers like Andrew Shonfield who viewed the 'mixed economy' as the instrument through which government damped down oscillations in activity and sustained the economy at a higher employment equilibrium than in the inter-war period. ${ }^{11}$ Where governments accepted responsibility for aggregate economic management they were able in most cases to maintain adequate levels of demand to attain a full use of resources. Maddison emphasized three areas of policy in particular; the higher level of government current expenditure on goods and services as a proportion of GNP; housing policy; fiscal policy. He saw governments as consciously using all three as stabilizing devices and although he was careful not to attribute any of these policy devices to the direct influence of Keynesian prescriptions, the historical specificity of the weight he placed on government policy is that changes in economic theory were used to justify stabilization through demand management. How far is this additional element of historical specificity borne out by historical research?

Although the objectives of economic policy in Western European states were certainly more similar than they had been in the inter-war period, the assumption that they were influenced in this similarity by the shift towards Keynesian economic theory has not been borne out. The objectives of economic policy in Germany and Italy were often very different from those in France and in none of these three major states did Keynesian economics have a noticeably strong influence over policy formulation in the 1950s. That governments did in fact, with considerable differences of method and emphasis, pursue expansionary policies was more due to the fact that an early commitment in 1945 to this objective proved not to pose insuperable political and

10. A. MADDISON, Economic Growth in the West. Comparative experience in Europe and North America, The Twentieth Century Fund, New York, 1964, p.99.

11. A. SHONFIELD, In defence of the mixed economy (edited by Z. SHONFIELD), Oxford University Press, Oxford, 1984. 
economic problems beyond the time horizon for which it had been originally envisaged. Reconstruction, recouping the losses ascribable to war, turned into sustained expansionary policy for two reasons which had little or nothing to do with changes in economics and their influence on governments. One was the fundamentally different nature of governing political coalitions after 1945. The other was the much more favourable international environment.

The experience began with a restocking boom like that of 1919 combined with a search for legitimacy of governance within the restored nation-states. These impulses were common across almost all western European states. Keynesian economics entered into the story only where it was used as a justificatory ideology for the second impulse in those countries, the United Kingdom, Sweden, and France, where it had begun to have intellectual influence in the late 1930s. Even in Britain, as studies of policy-formulation have shown, Keynesian ideas only influenced policy-formulation by the mid-1950s whereas from 1945 onwards they were frequently used after the event to justify policies whose causes lay much deeper in the political system.

There may be good grounds for arguing that the restocking boom after the end of the Second World War was likely to last longer than after the First. The physical damage done by fighting during the First World War had been confined to a smaller area and the damage to housing, transport and other forms of fixed capital caused by bombing was far more restricted. The difficulty with this argument is that the high levels of investment which prevailed in western European economies from 1945 onwards were by no means due merely to replacement investment. Much of it was new investment and in some cases replacement investment was deliberately postponed so that new investment would not be too much impeded. One of the most striking aspects of the distribution of post-war investment in western Europe is that a higher proportion of capital investment was devoted to housing in Britain than in any other economy, although the damage done to the total housing stock there was less than anywhere else except the neutral countries. And if in retrospect it appears that there was over-investment in this sector, the comparison would still have to be made with the meagre allocation of investment funds to housing under the French Modernization Plan after a long period of low investment in the same sector before the war. These were fundamental choices by governments armed with every sort of control over the housing sector and they were to lead to a very obvious difference in social conditions in the two countries over the next twenty years. In Italy, where the damage to housing stock had been even worse, the proportion of investment allocated to its rebuilding was even lower than in France.

It would be fallacious to assume in fact that, could a neat distinction be drawn between investment determined by the need to recoup war damage on the one hand and new investment on the other, countries switched from replacement investment to new investment between the end of 1947 and 1948. The two kinds of investment are not only virtually impossible to separate but countries had little intention of trying to separate them, because damage done to fixed capital during the war offered an opportunity for a rationalization and modernization in the appropriate sector which 
almost always implied a different distribution of capital within the sector and also a larger volume of capital investment than was necessary merely to recoup the damage done during the war plus the investment foregone.

The best guide to the pattern of investment in 1949 is in the separate plans which the European economies published at the close of 1948 when they failed to produce the common medium-term plan which had been requested from the OEEC. These show how a mixture of new and war-determined investment was planned for the period of 1949 to 1952-53, as well as the large amount of investment which could unambiguously be classed as new. The estimates submitted to the OEEC, however, were only investment intentions and in some areas in 1949 the climate was decidedly less expansionist. It was, for example, publicly questioned whether the steel industry was not grossly over-equipping itself in the light of future market forecasts. It is sometimes suggested that the reconstruction boom had run out of momentum in 1949 because the task of physical restoration was over, leaving in isolation a set of ambitious investment plans which could not be justified. The timing of the onset of the American recession in late autumn 1948, the fact that one of its principal aspects was a steeper fall in stocks than in output, and the fact that it was especially felt in capital goods industries, all tended to support that view. Sometimes the suggestion is extended into an argument with much more sweeping consequences for an explanation of the post-war period, that the reconstruction boom sustained the capitalist economies to the winter of 1948-49 and that they then began to enter into a period of depression from which they were only rescued by the Korean war, rearmament, and a permanently higher level of defence expenditure. If this were the case there would obviously be no inherent connections between the boom which accompanied reconstruction and the later prosperity.

But it is not the case. Sweden appears to be the only country in western Europe where total fixed investment fell in real terms throughout 1949. Industrial production there rose only sluggishly throughout the year. In Belgium and Luxembourg it fell after the first three months of the year so that by the end of 1949 it was again below the 1938 level. In Luxembourg the fall was especially steep and indicates the root of the problem, steel, which dominated Luxembourg's output. The severity with which Belgium and Luxembourg suffered from the slackening in the overall demand for steel was directly related to the fact that their steel industries depended on exports. Their export prices were too high and as other sources of similar steel became available on export markets the Belgian franc became a hard currency for steel buyers. As in other sectors Belgium's failure to participate fully in the reconstruction boom after mid-1948 appears to be related to the failure of an open economy whose prosperity was geared to foreign trade to make the necessary structural adjustments to fit its situation and policy. Throughout the reconstruction period, as we have seen, the blame was always placed by the Belgian government on the imperfections of western Europe's trade and payments mechanisms. Had they been more perfect and returned, as the Belgians wished, to something akin to the gold exchange standard, the effects on Belgium's steel industry would only have been harsher and the need for a restruc- 
turing of industry yet more urgent. Industrial output in the Saarland, where steel had a comparable weight, climbed throughout 1949.

For the rest of western Europe 1949 was a year not only of sustained high investment but also of sustained growth of output and national incomes. The effects of the American recession were seriously felt only in exports and the balance of payments. Industrial output increased in every quarter except the third and full employment continued. When the American restocking boom burst it did not reproduce the pattern of 1920-21; western Europe remained prosperous, growth rates stayed high for the most part and investment did not falter. The reasons why the United States recession was not longer and deeper are themselves pointers to the favourable background conditions in Europe and show that the economic circumstances were not the same as in 1920. Consumption in the United States did not fall, with a slight drop in interest rates the domestic housing market soon picked up, and a varied collection of new and rapidly developing industries remained relatively unaffected. None the less, it is still necessary to explain why the American recession, even if it did not have repercussions in western Europe of the kind that occurred in 1920, did not produce a downturn in European investment.

The relative immunity of western Europe to American conditions in 1949, reproduced in 1953 and 1958, and the persistence of the boom was not due to public investment alone or to levels of government consumption higher than before the war. Private investment was buoyant and except in France and Italy it amounted to about two-thirds of total investment. Evidently private investors did not share the fears of some politicians in 1947 that the Russians would soon be in Calais banging away with their guns at Dover. Of course, physical reconstruction encouraged by government aid, extensive nationalization in Britain and France with concomitant investment programmes, and the interposition of numerous intermediate managerial organizations between government and industry, all with more or less positive programmes of action, encouraged a favourable climate for private investment as well. But private investment on this scale would not have taken place without very favourable judgments of future market conditions independent of the market provided by government.

The share of national income taken by government consumption in 1949 was almost 50 percent greater in the Netherlands and Sweden than before the war and about a third greater in Denmark, Norway and the United Kingdom. Elsewhere the difference was insignificant, although it has to be borne in mind that in pre-war Germany (including Austria) government consumption took up about a quarter of national income. This was certainly a characteristic of post-war economies and it was to persist. None the less to explain the persistence of the boom the potential of private markets is needed.

The buoyancy of private investment until late in 1948 is probably best explained by the favourable conditions created by the persistence of governments in the face of many international obstacles in maintaining high levels of reconstruction expenditure. Even before the end of 1948, however, the steep increases in real earnings in 
most countries and the great increase in the total volume of earnings in many were opening up an enticing prospect of a rapid growth in consumer goods markets. There were few countries where the higher levels of disposable purchasing power could be freely translated into consumption. Relatively low levels of consumer goods output, trade controls practised against consumer goods imports, fiscal policies aimed at encouraging investment, and still in many countries rationing and other physical controls on consumption meant that the backlog of consumer demand and the accumulation of unliberated purchasing power were creating a potential consumer goods market capable of very rapid expansion when permitted. In some countries, Britain, Sweden and Switzerland for example, high and increasing real earnings and low levels of consumption had existed together for almost eight years by the start of 1949 .

Omitting France and Germany from the calculation the average level of real earnings of industrial or manual workers in western Europe in 1948 was almost a fifth higher than in 1938. For all countries for which a meaningful calculation can be made the share of wages in the national income had risen markedly compared to pre-war. Only in France was this not the case and there was probably a sharp fall in wageearners' purchasing power there in 1947. But by the end of 1948 the ground lost in the previous year had been recovered. Between the first quarter of 1946 and the last quarter of 1948 the purchasing power of the hourly wage in France increased by 20 per cent, so that in spite of the vicissitudes of 1947 French wage-earners had achieved a comparable rate of increase in purchasing power to those elsewhere in western Europe.

The rise in wages and in personal disposable income, reflected in the steep increases in consumer goods purchases from 1949 onwards in all countries is evidence that there were other forces than restocking contributing to the high levels of investment in the years 1947-49. The history of 1947 itself however is even clearer evidence. In a situation where machinery and other capital goods were to be obtained only with dollars, Germany's exports having been reduced to coal and trees, and where dollars were the scarce currency, dollar shortages and increasing trade deficits would have brought the boom to its expected end in several major countries in spring or summer 1947. Trade deficits actually increased steeply over the first six months of that year in the United Kingdom, Italy, the Netherlands and, to a slightly less degree, in France, and did so as American reconstruction aid was running to its end. In any previous period policy would have had to change to deflation. Without any grounds to suppose that America's global aid would be continued in the form of Marshall Aid countries nevertheless continued unswervingly along the expansionary path even when foreign exchange reserves were virtually exhausted, relying on an ever-increasing battery of trade, exchange and other domestic controls. The legitimacy and survival of their governments depended on not changing course.

For this, as for the steep rise to real wages, the reasons are to be found in the altered political economy of the post-war state. Most nation-states had lost much of their claim to the allegiance of their citizens after 1939. Unable to defend either the lives or the property of their population they could lay no claim to legitimate restoration 
other than their past legitimacy in 1940, from which date their citizens or subjects had looked back in most cases over ten years of social and political divisiveness which themselves had greatly contributed to the collapse of national government. The postwar state was reconstructed on a much wider political consensus than that which had shaped policy in the inter-war period. Into this consensus were brought three large, overlapping categories of voters whose demands on central government had been hitherto imperfectly met or even refused: labour, agricultural producers, and a diffuse alliance of lower and middle income beneficiaries of the welfare state. The further extensions of the franchise which took place after 1945 provided one of the impetuses to that political reconstruction, but were not the greatest of them. The more powerful impulses were the desire for security, the general sentiment that only the nation-state could offer it, and the need for national parliamentary government to restore its legitimacy by purchasing allegiance. A further component in the model of the reconstructed state was the transformation in the nature and role of political parties in response to these impulses. They became the sensitive measure of a much larger public opinion than had been taken into account by the pre-war state - hence the sudden rise to prominence of the public opinion poll - and the conduit by which demands for concessions were transmitted to the parliamentary centre. It was they who had to undertake the necessary brokerage at the centre to keep the new consensus together. The national parliaments became the arena in which they performed stylized rituals which ratified the policy choices already made from the assessment of information gathered deep in the roots of local society and government where they now began to function.

The Christian Democratic parties in Italy and Germany are paradigms of a successful adaptation by political parties to this larger and deeper framework of democratic politics. Their influence over appointments and general favours reached down to the most local level. A party like the Italian Christian Democracy or the Social Democratic Party in Sweden, could aspire to become a state-party, in almost permanent power providing it was able to continue to embrace all the elements out of which the new political consensus was formed. In other states, Austria being a good example, political parties shared out the power in systems which were basically non-adversarial because consensus was sufficiently close for them to share at local and national level the power which it gave to them. The difference between the post-war Christian Democratic Union in Germany (CDU) and the inter-war Zentrum encapsulates the way in which the role of political parties changed. The Zentrum was almost wholly a catholic party essentially under the political domination of the catholic hierarchy and taking its political positions in parliament according to that hierarchy's wishes. It was typical of most pre-war political parties in western Europe in that it more resembled a club of like-minded individuals associating to vote together at the parliamentary centre than a machine for discovering the demands coming from below in society and transmuting them into policies. The CDU by contrast very quickly became a complicated and pervasive political machine, whose parliamentary positions were shaped by responses to pressures from below, rather than from above. 
It was the broader post-war political consensus and the political machinery by which it was operated which led to the economic and social policies to which growth theorists point as part of their explanation for the high rates of growth of the period. The reassertion of the nation-state, because it required the satisfaction of so many demands if it were to succeed, was the start of the higher growth rates of the postwar world. This does not mean that government policy was the chief cause for those high growth rates. But as long as they were achieved they strengthened the reassertion of the nation-state, so that from its collapse in 1940 it had achieved in twenty years a degree of power and legitimacy founded on an allegiance stronger than any in its previous history.

The incorporation of organized labour into the machinery of policy formulation of the post-war state has been frequently noted. It was, as Charles S. Maier has cogently argued, a conscious post-war bid for political stability. ${ }^{12}$ The way in which this covenant was encouraged by American aid during the Marshall Plan has been illustrated by several authors. But in most countries it could make little difference to establishing political power, because organized labour was so small a part of the total labour force. The acceptance of the political status of trade unions is better understood as one small part of the response to much more complex demands for welfare relating to the whole of the labour force and carried to the top of the political agenda by political parties dependent on the votes of wage labour. This response was announced in the sweeping wage increases granted as almost their first political act by the liberation governments in Belgium and France. In several countries, notably Sweden and the United Kingdom, this response took the form of a public commitment to full employment policy.

John M. Keynes provided the intellectual justification for the argument that governments could eliminate long-term mass unemployment by manipulating the level of aggregate demand. Writing when unemployment in the United Kingdom was the lot of 17 per cent of the labour force, Keynes variously estimated the equilibrium level of employment at between three and six per cent and his theoretical and empirical work was concerned with the shaping of policies which could return the economy to that equilibrium level and keep it there. The policies suggested by this work, deficit spending from government budgets at the bottom of cyclical troughs, regulation of the level of demand by changes in fiscal policy and by adjustments of the volume of money and credit, were used as regulators of the economy and the employment level. The level of unemployment in the period 1950-69 however was not only dramatically lower than in the 1930s, it was also much lower than the levels at which Keynes had suggested his policies should be put into practice. The causes for these high levels of employment went far beyond government commitment to Keynesian policies, strictly defined.

12. C.S. MAIER, The Politics of Productivity: Foundations of American International Economic Policy after World War II, originally published in: International Organization, September(1977), pp.607634; and The Two Postwar Eras and the Conditions for Stability in Twentieth Century Europe, in: The American Historical Review, 2(1981), pp.327-352. 
None the less, the motive that inspired Keynes was widespread; to rescue the capitalist economy by eliminating a waste of human resources and an economic injustice which had weakened the allegiance to the state. Even in the Federal Republic when in the 1967 recession the economy first appeared unable to continue to increase the number of jobs available, the principles of Keynes's work were officially enshrined in a law to promote the stability of growth of the economy. The high levels of employment achieved everywhere were in fact in large measure a result of the way other economic policies emerging from the new consensus sustained the demand for goods, and in so doing met more political encouragement on the grounds that they induced growth and employment than discouragement on the grounds that they were inflationary.

A second common feature of the post-war state is that support by the state for incomes in the agricultural sector became a universal practice on a large scale. The widening gap between incomes in manufacturing and agriculture had been one of the main causes of the fracture of the political base of democracy in the inter-war period, especially over the period 1929-32 when agricultural prices fell three times as steeply as those of manufactures. Support for authoritarian movements became a notable feature of the politics of agricultural regions even in highly industrialized states like Germany. Voters there whose livelihoods depended on agriculture supported in turn almost the whole gamut of non-socialist parties before turning to the national socialists and giving them for the first time in 1930 a large parliamentary representation. It was the discontent of agriculture in northern Italy which first laid the power base of the fascisti. In Austria, a wide collection of antidemocratic movements relied on rural support. A priority of the post-war state everywhere in western Europe was to forestall any similar future developments.

In effect, agriculture became a state-managed concern, one of whose central purposes was to support and raise incomes in the sector relative to those elsewhere in the economy. As a general estimate it seems fair to conclude that by 1960 threequarters of the farmers in western Europe had a large supplement to their incomes as a result of state policy. This was a lot of votes in the 1950s, 6.8 million in Italy, if agricultural labour is also included amongst the beneficiaries, and five million in the Federal Republic.

The third common feature of the consensus is those sets of policies loosely referred to as the welfare state. National welfare regimes came in different political forms, because their earlier historical origins were different, because the state-machinery varied, because they were animated by different political philosophies, and because the specific concessions which they offered were to different categories of voters. The sweeping reform of the German pensions system in 1955-57, a bid by the Christian Democratic Union for long-term middle-class electoral support, had little in common for example, with the extension of public welfare in Sweden or Norway except an adherence to the view that the stability of the state required a positive response to the demand for welfare. The assimilations however are justified, both because the underlying political motivation was broadly similar, a bid for the electoral 
support of that large and rapidly growing income group, loosely defined as the lower middle class, whose propensity to switch votes had become a decisive factor in elections, and because in consequence the increase in magnitude of the provisions is general to countries but unique to the period.

Nowhere in the 1940s had private or corporate welfare schemes catered cheaply or efficiently enough to the needs of a sufficient number of citizens to bind them into a lasting allegiance. It was the use of state-supported insurance funds, offering a much more consistent pattern of security to a broader stratum of voters, which was adopted as the main way of remedying this defect after 1945 . The commitment of the postwar state to this generalized form of welfare appeared as an extension of earlier middle-class demands for a vote and participation in the state; the right to the vote, once obtained, was followed with demands for the right to welfare. Scarcely a year passed in western European states after 1945 without the extension of these new rights to some group or other. Pension coverage, for example, was extended to additional groups in Italy in 1945, 1950, 1957, 1958, 1959, 1963 and 1966, health insurance coverage in 1945, 1953, 1954, 1955, 1956, 1959, 1963 and 1966.

The index of social insurance coverage for western European states compiled by Peter Flora and Jens Alber shows that the evolution of this type of welfare provision was not evenly spread over time. ${ }^{13}$ For almost every western European country one particular period of exceptionally rapid increase is apparent, for Belgium the period 1944-46, for Switzerland 1947-48, for the Netherlands 1951-57, for Sweden 1955, for Norway 1956, and for Italy 1955-60. Weighted indices of this kind could be constructed according to different principles and give different results. Flora and Alber do not, for instance, single out the period 1945-50 in the United Kingdom, because the weights they use mean that social insurance coverage already appears as very high there before 1945. But all historians agree that this was the period of decisive extension of British welfare provision. Although the extension of welfare provision continued throughout the 1960s everywhere in western Europe and on a financially much more ambitious level than before, it was the continuation of a process which had usually established itself in a political breakthrough before the mid-1950s.

Over the whole period 1945-68 social insurance played the key role both in extending welfare and using welfare extensions to build and sustain consensus. It created a robust national framework of personal claims on the state's finances, mediated through a rapidly expanding welfare bureaucracy. This huge extension of state welfare cannot be historically characterized in abstraction from the massive and vigorous exercise of political rights which gave rise to it. Otto von Bismarck, in pioneering the concept of state-supported social insurance in the 1880s had hoped that workers would find it a substitute for political rights. It became, on the contrary, part of the continuum of political rights for which citizens have extended their demands since the French Revolution. William Beveridge's dry actuarial report on the unification

13. P. FLORA, J. ALBER, Modernization, Democratization, and the Development of Welfare States in Western Europe, in: P. FLORA, A.J. HEIDENHEIMER (eds), The Development of Welfare States in Europe and America, Transactions Books, New Brunswick, 1981, pp.37-80, here p.55. 
and extension of the existing social insurance schemes in Britain became a best-seller during the war, the symbol of national renewal, because in language and thought its one readable passage so unreservedly encapsulated the desire for personal security and the concept of all citizens as equally privileged members of one nation. ${ }^{14}$ Lukewarm support and spasmodic opposition cost the country's great, uncomprehending wartime leader the first post-war election.

The extension of the social insurance principle was not the only aspect of general welfare provision by the post-war state. Welfare in the widest sense, embracing almost the whole range of economic and social policy, was probably the issue most susceptible to manipulation for electoral purposes. The real growth rate of all social expenditure at 1970 prices in pre-election and election years in the Federal Republic between 1950 and 1983, for example, was always one per cent higher than in other years. The welfare state was also a commitment to the extension of public provision of housing, education, leisure and health.

Attempts to measure the increase of welfare provision in the widest sense have been made by Flora and his collaborators. In western Europe as a whole social security expenditure, including all income maintenance and public health programmes, averaged about 9.3 per cent of GNP in 1950 and 13.4 per cent by 1965. If spending on education and housing is included expenditure on welfare rose from about 25 per cent of GNP in 1950 to about 45 per cent by the mid-1970s. Dwellings completed by public authorities, usually local government with the help of the central state revenue, accounted for more than 70 per cent of the new dwellings completed in 1949 in France, Germany, the Netherlands, Norway, Sweden and the United Kingdom. In the Netherlands they made up 97 per cent of the total. The allocation of public housing could also create a political core of supporters for certain political parties, as well as being a valuable instrument of political manipulation at local level.

The outcome of what was only political pragmatism came to have a surprisingly coherent theoretical economic appearance. Support for agricultural incomes was an essential support to the welfare state; poor farmers would otherwise have made bigger demands on social insurance systems. High levels of state expenditure on housing construction and other aspects of the economy, such as defence and social security, sustained employment levels by sustaining demand. Full employment gave social insurance a much sounder actuarial basis. Social insurance systems, in their turn, provided governments with a larger financial reserve with which to pursue the counter-cyclical economic policies aimed at maintaining high employment. This apparent coherence was largely coincidental, both in thought and action.

The finer aspects of demand management, the use of fiscal policy and alterations in interest rates to stabilize demand and reduce economic fluctuations, have not been judged a success. Reactions to reflationary or deflationary adjustments of this kind in Britain, for instance, usually occurred after a longer time lag than foreseen and could thus exaggerate rather than diminish cyclical fluctuations. And the pressure to

14. W. BEVERIDGE, Report on social insurance and allied services, HMSO, Cm. 6404, London, 1942. 
concede welfare increases before impending general elections usually overrode more abstract principles of demand management. It is not only in the United Kingdom that almost every pre-election budget since 1950 has been more than normally inflationary. If governments were not successful in fine tuning the economy according to Keynesian prescriptions, the trend line of income growth was nevertheless higher and steeper because of the increase in size of the national budgets, whether balanced or not, because of the massive and stabilizing impact of the states' other interventions, and because of the microeconomic activities of government in stimulating particular industries.

Government budgets, released from the alleged necessity of being balanced, were growth-inducing, because their role in maintaining the new political consensus made them so much larger than earlier. Hansen estimated that over the period 1955-65 the total effect of the government budget, including local authority budgets and investment by the state in public enterprise, accounted for 18 per cent of the actual growth rate of GNP in Italy and Sweden, and in France for 12.5 per cent. The calculation is necessarily a rather narrowly-based one. It cannot take into account for example the effect of high and predictable levels of government expenditure on mood and the climate for investment. This was particularly important where the state regularly published its expansionary investment intentions in advance, as it did in the case of the French plans or the Norwegian 'national budgets'. When government consumption and expenditure took up so much larger a share of national income, the psychological influence of the government's general stance towards the economy could be of great consequence.

As soon as we look at total government expenditure the increased financial weight of the post-war state in the economy becomes more evident. Total government expenditure as a share of GDP at current prices moved upwards relentlessly in western Europe as a whole. For this upward movement the overwhelming reason was the transfer payments made to support the welfare state. In some countries in the 1950s, including France, Germany and Italy, these were larger than government spending on goods and services. The precise effect on demand of these massive transfers, the single most obvious consequence of the politics of the post-war state, has been the subject of incessant political argument. They were essentially transfers of the burden of taxation from the better-off to the less well-off citizens and so reduced the personal disposable income of some consumers below what it would otherwise have been. At higher levels of unemployment, such as still obtained in the 1950s in Belgium, Germany and Italy, they clearly did help maintain demand, because of the much higher level of unemployment benefits compared to before the war. It seems highly probable also that the redistribution of purchasing power which they brought about favoured the growth of the mass markets and standardized patterns of consumption on which so many of the productivity gains of manufacturing industry in that period depended. Full employment plus income redistribution created a large new body of consumers. The most striking example comes from the ageing of western Europe's population. With pre-war welfare provision this would have meant that a far greater proportion of it would have been in that stage of the life cycle when its income and consumption 
were close to or below the poverty line. Transfers maintained the aged as active consumers, albeit at a low level. If a collapse of demand as catastrophic as in 1929-32 did not occur in 1989, even though governments seem to have left themselves with few fiscal or monetary weapons, that is largely because of the built-in stabilizers which now exist through the development of the welfare state.

Out of the similarity of post-war political coalitions came that international circumstance which most favoured the continuation of the boom, the limited surrenders of national sovereignty in the process of European integration. These had the very opposite significance than the description of them in integration theory as the gradual supersession of a functionally inadequate nation-state. The policies which strengthened the new national political coalitions and through which they repurchased allegiance were in most cases easier, and in some cases made possible, through the process of European integration. The surrenders of national sovereignty which were made were all for the purpose of strengthening the capacity to pursue national policies. The European Communities were the flying buttresses which held up the complex sheltering walls of ornate national cathedrals. Much of my work has demonstrated this at probably excessive length, so it would be tedious to do more than reiterate this here for the purpose of raising a different discussion. If the reconstructed European nation state was able to sustain the great boom because of its capacity to cooperate in reshaping the international framework in this way, is the present European Community doomed because it is only an incidental product of a set of similar domestic policy choices which since 1974 have become dissimilar? What ended the great boom? And does its end portend the end of European Union?

\section{The End of the Great Boom}

There were never any good grounds for supposing that Keynesian economics had sufficiently powerful prescriptions to deal with the changing economic conditions after 1968-74. Research on the efficacy of government recovery policies after 1929-32, briefly summarized, would imply the following.

Firstly, there are no examples of Keynesian deficit spending policies having been effective enough to cope with falling demand and unemployment on such a scale, and no evidence that they could have been. If Sweden spent slightly more money per capita on public works and unemployment relief as revenue fell, it was, firstly, returning to an older tradition rather than pioneering the way to a new and more expansive role for state budgets and, secondly, as in Germany and the USA the increase in public expenditure on job creation programmes was incremental, piecemeal and, as in most countries now, designed more to get the unemployment statistics down than to create real jobs. It was cost ineffective in all three countries in terms of both the absolute number and quality of jobs created. We should have no confidence that government action in 1974 (or now) along similar lines could have done more than 
slightly alleviate at great expense the fall in employment and demand. In both cases that fall was superimposed on a period of important structural change in the nature and geographical pattern of employment.

What does emerge from studies of the 1930s is the importance of political coherence, of a durable coalition of political interests, in bringing confidence. That was what the New Deal was, for as anything else it is impossible to describe. If Franklin D. Roosevelt's policies were only a series of impulses, frequently contradictory, usually traditional, rarely in themselves conducive to recovery, they held his coalition together. Much the same is now accepted about the Nazi party regime in Germany after 1933 and the Swedish social democrats after 1932. The most striking example of the failure of political interest coalition building and a downward spiral of confidence comes from the major country which was hit the least hard by the Great Depression, France. Governed in the absence of such a political coalition by a core of administrators with no new impulse and only traditional policies to administer, it was the one major country that did not recover. The lesson of historical studies of the inter-war period is thus also that very limited though policy will be in its effects, it is better for government to act than not, but that action depends on the coherence of a political coalition.

Such conclusions have of course provoked studies of how government could act to raise demand. These have offered some support to one of Maddison's three contentions: well-aimed fiscal policy was useful. In the case of the German recovery after 1932 this conclusion perhaps offers support to another of his contentions, that government intervention in residential construction raises demand consistently. Subsidies to house construction and repair in Nazi Germany were successful and costeffective in increasing the number of people re-employed as well as raising demand through the multiplier. The other measurably effective way of increasing demand in the 1930s was through systematic aid to agriculture. This was of course a crucial element in durable coalition building in the USA, Sweden and Norway, where events foreshadowed the more generalized post-1945 West European pattern. The historical lesson of the fifty years that followed will almost certainly be that the costs of this to the economy had necessarily to be borne and soon became but a small fraction of the gains from higher demand levels. The capacity of governments to deal with the events of 1968-74 can best be assessed in the framework of this analysis of 1929-32.

The general descriptions of the great boom with which we began imply different versions of its end, some sudden, some gradual. The argument that it came to a sudden end relies on the sharp break in 1974-75 in employment growth (but not in unemployment trends). The growth of total factor productivity also shows a clear break in trend at the same time; after 1973 it is much lower. But since in the earlier period productivity grew more rapidly with more rapidly rising employment, it is a sustainable hypothesis that the break in the trend of total factor productivity growth is connected with the fall in output and employment. The argument that the great boom faded away derives from those descriptions of the boom as a long slow-down in rates of productivity growth, either because that was inherent in the catch-up process or 
because higher labour costs, by reducing the returns to capital, gradually reduced investment ratios. In this type of argument the inflationary movement induced by the rise in raw material input costs would mark a turning-point but not be in itself the sudden cause of the end of the boom.

The scant historical evidence which would allow us to decide between these scenarios points however so far to an analysis more consistent with the analysis of the end of the great boom, like the capacity for limited recovery after 1945, having also depended crucially on the political economy of democratic interest building. Some governments in 1974 gave way much more readily than others to inflations with which they could have coped. 'New', supply-side economics was used to justify a set of political choices in much the way that Keynesian economics was used to justify different choices after 1945 .

In historical perspective it will seem very odd that so much of the discussion in 1968-74 was about wages and wage-inflation. Historians are unlikely to accept that there is any evidence for a functional relationship between the level of unemployment and the magnitude of wage increases (whether through the Philips Curve or its modern successor the NAIRU). ${ }^{15}$ The evidence is not there that lower levels of employment were accompanied by sustained higher wage settlements. There is evidence that the very course of the great boom so attenuated these links that they became of little consequence in the boom's end. Such a connection depends on changes in import prices, on the level of previous wage settlements, on the trend in profits, and on the political climate, to name but four variables which were moving in different directions in most of the economies concerned. The trends of 1945-68 which reduced, contrary to the general line of argument of Glyn and Harrison, the importance of labour costs in prices, and especially in export prices, certainly continued well after 1974, whatever the situation now. Hourly manufacturing costs and unit labour costs were falling in United Kingdom manufacturing in the 1960s compared to those in Germany over the very period when German exports were increasing largely at the expense of British. It is only in the last three years, when hourly costs in UK manufacturing are about half those in Germany, and unit costs lower still in comparison, that this trend has been clearly reversed.

The response of government to the increasing budgetary burden of welfare was also premature. Unemployment compensation was the most rapidly growing item of social expenditure in 1969-71 and again after 1974 but its absolute burden was the smallest of all the separable categories of welfare expenditure. The implication of the lower levels of demand after 1974 was that increases in social security benefits on the scale on which these had taken place in the great boom were no longer available as instruments of political coalition building without economic danger. But there was no need to reduce the level of real benefits unless the relative prices of education or health care rose faster than they had been doing or unless demographic predictions changed drastically. If gains in benefits were conceded after 1974, this, like the excessive concentration of policy on wages, reflected changes in government coalitions,

15. NAIRU stands for Non-Accelerating Inflation Rate of Unemployment. 
the gradual replacement of the political economy of the period 1945-68 by another one.

What has emerged is difficult as yet clearly to describe. Equally difficult to analyse - rather than speculate about - is its consequence for the international framework which emerged as an essential prop of the great boom. For the rest of the world it is probably this international consequence which is of the greater importance. This question has been directly raised by Perry Anderson in the pages of the London Review of Books in January, and with immediate reference to the ideas sketched out in this paper. ${ }^{16}$ Essentially, the question he raises is whether the Treaty of Maastricht and its central integrationist idea, European Monetary Union, not only spells the end of the political economy described here as sustaining the great boom but the creation of an international framework for a fundamentally opposed, deflationary, set of national policies for which integration is equally necessary. The applicability and force of the question can hardly be denied, and some answer to it must properly form a conclusion here.

The answer, though, can only be speculative, whereas this discussion paper sums up, however inadequately, a massive amount of historical research. Not wishing to mix up research and speculation I have appended separately, as a further discussion paper, my brief answer to Perry Anderson, for it seems to me that he raises the question with some answer to which any interdisciplinary discussion of these issues must conclude. ${ }^{17}$

16. P. ANDERSON, Under the Sign of the Interim, in: London Review of Books, 4 January 1996, pp. 13-17; reprinted in P. GOWAN, P. ANDERSON (eds), The Question of Europe, Verso, London and New York, 1997, pp.51-71.

17. Alan S. Milward's answer to Anderson was published as A.S MILWARD, Approaching Reality: Euro Money and the Left, in: New Left Review, March-April(1996), pp.55-65; reprinted after some editing as The Springs of integration, in: P. GOWAN, P. ANDERSON (eds.), op.cit., pp.5-20. 